\title{
Characterization of Traditionally Obtained Buffalo Cheese
}

\author{
Aurelia COROIAN ${ }^{1)}$, Cristian-Ovidiu COROIAN ${ }^{1^{*}}$, Vioara MIREȘAN $^{1)}$, Camelia RĂDUCU ${ }^{1)}$, Luisa \\ ANDRONIE $^{1)}$, Daniel COCAN ${ }^{11}$, Zamfir MARCHIȘ ${ }^{1)}$ and Octavian NEGREA ${ }^{1)}$ \\ ${ }^{1)}$ Faculty of Animal Science and Biotechnologies, University of Agricultural Sciences and Veterinary \\ Medicine, 3-5 Mănăștur Street, 400372 Cluj-Napoca, Romania \\ *Corresponding author, e-mail: coroian.cristian@gmail.com \\ Bulletin UASVM Animal Science and Biotechnologies 72(2) / 2015 \\ Print ISSN 1843-5262; Electronic ISSN 1843-536X \\ DOI:10.15835/buasvmcn-asb:11553
}

\begin{abstract}
In the past decades buffalo milk has attracted growing interest in most countries, especially due to its nutrition characteristics. In Romania, buffalo milk and milk products are mainly considered local and traditional resources, and play an important role in enhancing livestock biodiversity. Currently, the overall availability of milk from all dairy animal species, as well as the possibility of obtaining new products must be analysed. Buffalo milk composition is influenced by season. Milk fat level in autumn is $7.95 \%$, and in the summer it is $7.29 \%$. The highest mean values for the cheese were recorded in the spring season, with a fat and protein content of $41.02 \%$ and $21.34 \%$, respectively. In autumn, the fat content is at $36.92 \%$, and protein is at $19.81 \%$.
\end{abstract}

Keywords: buffalo, cheese, milk, physico-chemical parameters.

\section{INTRODUCTION}

The quality of cheese is determined by its texture, which is influenced by milk composition and processing conditions. The technological process of cheese production and milk composition (in particular the content of fat and proteins), as well the biochemical processes that occur during manufacturing affect the final quality of cheese (Coroian et al. 2011, 2012; Velea and Zanc, 2011). Buffalo milk is casein-rich, which is essential in obtaining fat cheeses, and lactose-rich (Sarfraz et al., 2008). Sensorial characteristics of the cheese are influenced by the type of milk used, the curing temperature, the starter cultures used and the period of ripening (Murtaza et al., 2013; Yazici et al., 2010; Rosati et al., 2002).

Telemea cheese made from buffalo milk, along with sheep and cow telemea cheeses, belongs to the category of cheeses ripened in brine. Quality requirements for good telemea cheese are directly influenced by the quality of raw milk (including sensory characteristics, physico-chemical and microbiological hygiene).

\section{AIMS AND OBJECTIVES}

The purpose of this study was to characterise cheese traditionally made from buffalo milk.

\section{MATERIALS AND METHODS}

10 milk and 10 cheese samples were analysed in each season. Every sample was analysed considering three parameters: physico-chemical composition, microbiological status and effect of the season. The main physico-chemical parameters of buffalo milk were analysed: fat, protein, lactose and total dry matter. These parameters were analysed with Lactostar automatic analyzer. Total number of germs (TNG) and the somatic cell count (SCC) were determined by BactoScan FC and BRT screening test, respectively.

\section{RESULTS AND DISCUSSION}

Total number of germs (TNG) in buffalo milk ranged within: $55.41 \pm 0.6$ and $98.6 \pm 0.7$. The number of somatic cells (SCC) ranged as follows: the lowest average values were $180 \pm 5.8$ and 

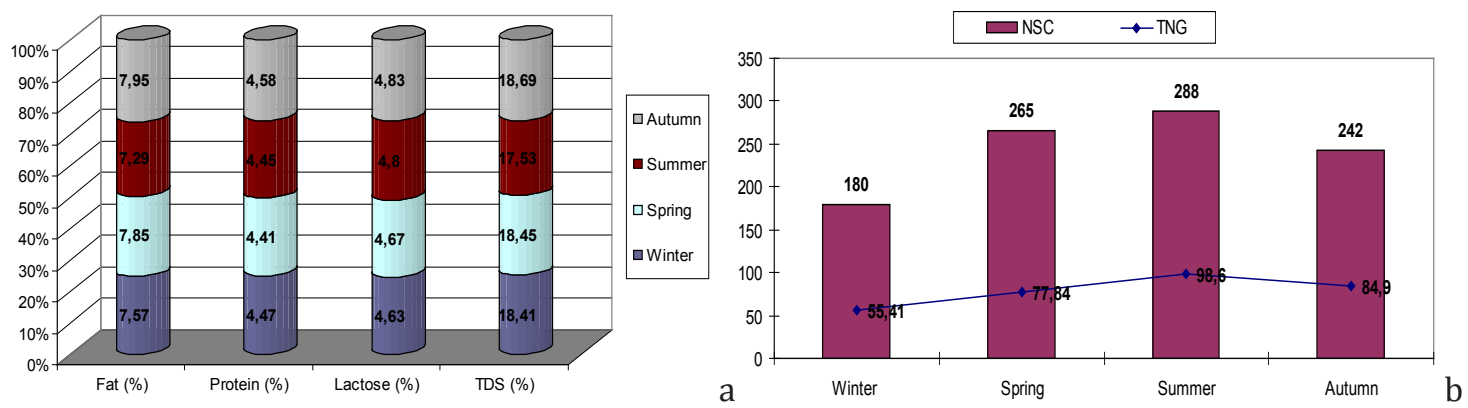

Fig. 1. a) Physico-chemical composition of buffalo milk depending on the season; b) TNG and SCC buffalo milk used to make seasonal cottage cheese

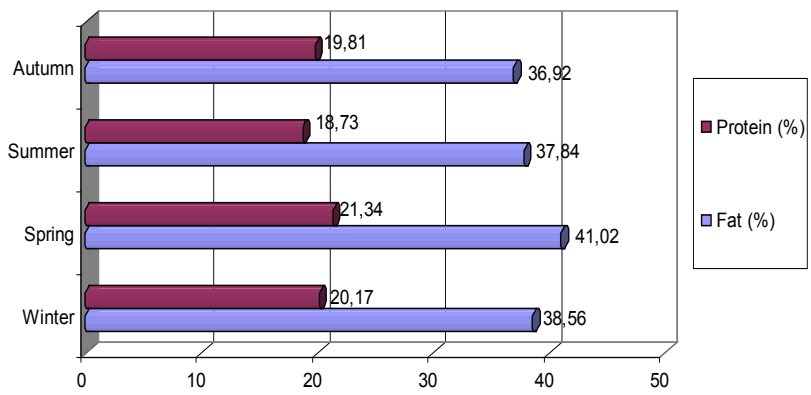

Fig. 2. The seasonal mean values for fat and protein of buffalo cottage cheese

the highest were $261 \pm 6.1$. Raw milk must meet the following quality requirements set by the European Comission: the total number of germs lower than $100,000 / \mathrm{ml}$ and total number of somatic cells under 400,000 cells $/ \mathrm{ml}$ (Council Directive 92/46/EEC). The milk used to prepare the cheese was approrpiate in terms of microbial load (figure 1, b). The mean values for fat content of buffalo telemea ranged from $38.56 \pm 3.21 \%$ to $41.02 \pm 2.17 \%$. Protein content ranged from $20.17 \pm 1.36 \%$ to $21.34 \pm 2.81 \%$ (figure 2 ). Velea et al. (2011) reported the following average values in buffalo milk: $8.3 \%$ fat, $4.6 \%$ protein, $4.8 \%$ lactose and total dry matter $18.8 \%$. Chindriş V. (1998) also reported similar values for fat and protein in buffalo milk.

\section{CONCLUSION}

Telemea is a product obtained from both cow's and buffalo milk taken separately, but also sometimes mixed, due to the insufficient quantity of buffalo milk. In these circumstances, local production of buffalo cheese can only be achieved by maintaining buffalo livestock. The importance of obtaining dairy products from buffalo milk can be justified in terms of the contribution they have to the economic and cultural aspects of life. In Romania, there is a relatively constant amount of milk, mostly cow's milk, and the more accessible option for processors is to use buffalo milk mixed with cow's milk for obtaining certain products.

\section{REFERENCES}

1. Chindriș V (1998). Calitățile igienice ale laptelui de bivoliță şi implicațiile acestora asupra produselor lactate. Teză de doctorat, Cluj-Napoca.

2. Coroian A, Coroian CO, Matea CT, Mireşan V, Odagiu A, Răducu C, Dărăban S (2011). Characterization of some milk components, function of lactation, in buffaloes. ABAH Bioflux 3(2):135-140.

3. Coroian A, Coroian CO, Trif M, Mireșan V, Răducu C, Cocan D (2012). Evaluation of buffalo milk depending on the content of somatic cells and the total number of germs. ABAH Bioflux 4(2):54-57.

4. Murtaza MA, Rehman SU, Anjum FM, Huma N (2013). Descriptive sensory profile of cow and buffalo milk Cheddar cheese prepared using indigenous cultures. J Dairy Sci 96(3):1380-1386.

5. Rosati A, Van Vleck LD (2002). Estimation of genetic parameters for milk, fat, protein and mozzarella cheese production for the Italian river buffalo Bubalus bubalis population. Livest Prod Sci 74(2):185-190.

6. Sarfraz A, Isabelle G, Florence R, Eric B, Michel P, Jean FG, Frédéric G (2008). Effects of acidification on physicochemical characteristics of buffalo milk: A comparison with cow's milk. Food Chem 10(1):11-17.

7. Velea C, Zanc C (2011). Creșterea și exploatarea bubalinelor. Editura Texte. Dej.

8. Yazici F, Dervisoglu M, Akgun A, Aydemir O (2010). Effect of whey $\mathrm{pH}$ at drainage on physicochemical, biochemical, microbiological and sensory properties of Mozzarella cheese made from buffalo milk during refrigerated storage. J Dairy Sci 93(11):5010-5019.

9. *** COUNCIL DIRECTIVE 92/46/EEC of 16 June 1992 